\title{
Global Environmental Governance Reform: The Emerging Debate on the Need for a World Environment Organisation
}

Empire Hechime Nyekwere*

DOI: $10.21827 / 5 b f 3 e 9 f 82617 e$

\begin{abstract}
Keywords
GLOBAL ENVIRONMENT; GOVERNANCE REFORM; CORE ISSUES OF DEBATE FOR REFORM; MODELS OF GOVERNANCE REFORM; WORLD ENVIRONMENT ORGANIZATION
\end{abstract}

\begin{abstract}
Environmental problems, such as climate change, ocean pollution, the depletion of fisheries, and loss of biological diversity, have come to demonstrate most openly our current global interconnectedness. Governments continue to set-up international mechanisms for tackling global-scale environmental problems which has led to a complex international bureaucracy, significant burdens on national administrative capabilities in both the developed and the developing world, and, most importantly, inability on the part of existing international or national bodies to successfully deal with the problems at hand. In this context, the question of the most suitable governance architecture for the scale and scope of contemporary global environmental problems has become an important focus of both policy and academic debates. Scholars and politicians alike have argued that if we do not address governance failures, our stewardship of the environment will persist to be ineffective and inequitable, with little possibility of finding a pathway toward sustainability. Consequently, national governments, civil society groups, and experts on global environment policy have called for the reform of the global environmental governance structure. This paper reviews the most prominent policy options for environmental governance reform that have received attention in the literature, and identifies key points of contention and convergence. To achieve its aim, the paper is divided as follows: introduction, core issues of debate on the need for a World Environment Organization, models of global environmental governance reform, arguments against a World Environment Organization and the concluding remark.
\end{abstract}

\section{Introduction}

In spite of the proliferation of institutions, multilateral treaties, mechanism and processes since the end of the 1990's, charged with stewardship of the global environment; the health of the global environment continues to deteriorate. ${ }^{1}$ As encouraging as the

* Lecturer, College of Law, Redeemer's University, Ede, Osun State, Nigeria. International Environmental Law Ph.D. Student at Faculty of Law, Department of International Law and Jurisprudence, Nnamdi Azikiwe University, Awka, Anambra State, Nigeria. The author is a Nigerian national and Barrister \& Solicitor of the Supreme Court of the Federal Republic of Nigeria. Email: empire.hechime@yahoo.com.

1 See Harada, N, Campaign for a Global Environmental Organization: A French Perspective, Prepared for Global Environmental Governance: the Post-Johannesburg Agenda, Yale Centre for Environmental Law and Policy New Haven, CT, 23- 25 October 2003, at <agirpourlenvironnement.org/pdf/harada.pdf> (accessed 18 November 2018) 6; See International Environmental Governance Stakeholder Forum for Our Common 
growing involvement of many different United Nations bodies in environmental matters is, what we have at present is duplication, fragmentation and inefficiency ${ }^{2}$ in the governance of the global environment. International environmental problems, such as climate change, biological diversity, drastically depleted fisheries, catastrophic droughts, devastated forests, disappearing freshwater resources, pollution of coastal zones and international waters, increase in the volume of waste (including radioactive waste), deforestation and desertification, privatization of natural genetic resources, progressive exhaustion of natural resources and the dispersion of persistent hazardous chemicals, remain largely unresolved which threatens delicate ecosystems and, indeed, the inhabitants of the earth. ${ }^{3}$

A comprehensive and systematic global environmental policy does not yet exist. ${ }^{4}$ The proliferation of weak international environmental treaties and national laws has failed to address the problem of global environmental decline. The various bodies that address environmental issues in some cases have conflicting mandates and lack sufficient authority and funding to prioritise the environment. Additionally, in contrast for instance, to the structure of the World Trade Organization (WTO) or International Labour Organization (ILO), the system of International Environmental Governance (IEG) has weak enforcement and compliance mechanisms. ${ }^{5}$ In this context, the question of the most appropriate governance architecture for the scale and scope of contemporary global environmental problems has become an important focus of both policy and academic debates. Scholars and politicians alike have argued that if we do not address governance failures, our stewardship of the environment will continue to be ineffective and inequitable, with little chance of finding a path toward sustainability. ${ }^{6}$ As a result, national governments, civil society groups, and experts on global environment policy have called for the reform and strengthening of the global environmental governance system. $^{7}$

Future Briefing Paper, 1, 5, at <https://sf.stakeholderforum.org/publications/reports/IEGSFpaper.pdf $>$ (accessed 4 January 2019).

2 See Oberthür, $\mathrm{S}$ and Gehring, T, "Reforming International Environmental Governance: An Institutionalist Critique of the Proposal for a World Environment Organization", 4 International Environmental Agreements: Politics, Law and Economics (2010) 359, 360; See Horta, Korinna, REPORT: The Global Environment Facility: The First Ten Years - Growing Pains or Inherent Flaws?, August 2002, at $<$ Halifaxinitiative.org/content/global-environment-facility-first-ten-years-growing-pains-or-inherent-

flaws-august-2002> (Accessed 17 November 2018); Gustave, S, Red Sky at Morning (Yale University Press 2004).

3 Oberthür and Gehring, supra nt 2, 360; United Nations Environment Programme (UNEP), Annual Report, 2000, at <wedocs.unep.org/handle/20.500.11822/7731> (accessed 17 November 2018); Pace, WR and Clarke, V, The Case for a World Environment Organization-Comments from the Federalist Debate, 2003, at <http://www.federalist-debate.org/index.php/current/item/575-the-case-for-a-worldenvironment-organization> (accessed 3 January 2019); Harada, supra nt 1.

4 Wissenschaftszentrum Berlin für Sozialforschung (WZB), Biermann, F and Simonis, UE, Needed Now: A World Environment and Development Organization, WZB Discussion Paper No. FS II 98- 408, Berlin, 1998, at <hd1.handle.net/10419/49574> (accessed 17 November 2018).

5 Oberthür and Gehring, supra nt 2.

6 Clapp, J and Dauvergne, P, Paths to a Green World: The Political Economy of the Global Environment (The MIT Press 2005); Young, OR, "The Institutional Dimensions of Environmental Change: Fit, Interplay and Scale" in Choucri, N, ed, Global Environmental Accord: Strategies for Sustainability and Institutional Innovation (The MIT Press 2002); Berruga, E and Maurer, P, Co-Chairmen's Summary of the Informal Consultative Process on the Institutional Framework for the UN's Environmental Activities, New York, 2006.

7 Yale School of Forestry and Environmental Studies (Yale F\&ES), Ivanova, M, Can the Anchor Hold? Rethinking the United Nations Environment Programme for the 21 $2{ }^{\text {st }}$ Century, Publication Series Report 
One response for international environmental governance reform is to create a World Environment Organization (WEO) that would be a designated and empowered advocate for the environment that could serve to ensure effective policy and decisionmaking and provide an adequate response to environmental management. ${ }^{8}$ Proposals to create an international agency on environmental protection have been debated for over forty years ${ }^{9}$ beginning with US foreign policy strategist George F. Kennan, who argued for an International Environmental Agency encompassing 'a small group of advanced nations' to bore the responsibility for solving international environmental problems. ${ }^{10}$ Several authors supported this idea ${ }^{11}$ at that time and as one outcome of this debate, the United Nations established in 1972 the United Nations Environment Programme (UNEP), ${ }^{12}$ following a decision adopted at the 1972 Stockholm Conference on the Human Environment. The creation of United Nations Environment Programme was a more modest reform than the strong international environmental organisation that some observers had called for at that time. Nonetheless, this reform altered the context of the organisational debate in international environmental politics and effectively halted it. ${ }^{13}$

The debate about a larger, more powerful agency for global environmental policy was revived in 1989 with The Declaration of The Hague, initiated by the governments of The Netherlands, France and Norway, which called for an authoritative international body on the atmosphere that would include a provision for effective majority rule. This declaration helped to trigger more proposals for a world environment organisation that could replace United Nations Environment Programme. ${ }^{14}$ At the June 23, 1997 Special Session of the United Nations General Assembly on environment and development, Brazil, Germany, Singapore, and South Africa submitted a joint proposal for a 'global umbrella organisation for environmental issues, with the United Nations Environment Programme as a major pillar'. ${ }^{15}$ In the words of Germany's chancellor at the time:

Number 7, September 2005, at <environment.yale.edu/publication-series/documents/downloads/ou/report_7_unep_evaluation.pdf> (accessed 17 November 2018), 11-12; Bharat, D, Institutionalizing International Environmental Law (Transnational Publishers 2004); Esty, DC, and Ivanova, M, eds, Global Environmental Governance: Options \& Opportunities (Yale School of Forestry and Environmental Studies 2002); Norichika, K and Haas, PM, eds, Emerging Forces in Environmental Governance (United Nations University Press 2004); Speth, JG, Worlds Apart: Globalization and the Environment (Island Press 2003); Vogler, J and Imber, M, The Environment and International Relations (Routledge 1996).

$8 \quad$ Pace and Clarke, supra nt 3.

9 Biermann, F and Bauer, S, eds, A World Environment Organization: Solution or Threat for Effective International Environmental Governance? (Aldershot, UK: Ashgate 2005); See Lodewalk, Magnus and John, Whalley, "Reviewing Proposals for a World Environmental Organization" (2002) 25(5) The World Economy, 601- 17.

10 Kennan, GF, To Prevent a World Wasteland: A Proposal, Foreign Affairs, (1970) 48 (3), 401- 413, at $<$ foreignaffairs.com/articles/1970- 04- 01/prevent- world- wasteland > (accessed 17 November 2018); Steffen, Bauer, The Catalyst Conscience: UNEP's Secretariat and the Quest for Effective International Environmental Governance. Global Governance Working Paper No 27, 2007, Amsterdam et al.: The Global Governance Project, at <www.glogov.org> (accessed 3 January 2018).

11 Stakeholder Forum, Biermann, F, Reforming Global Environmental Governance: The Case for a United Nations Environment Organization (UNEO), February 2011, at <ieg.earthsystemgovernance.org/ sites/default/files/files/publications/Biermann_Reforming\%20GEG\%20The $\% 20$ case $\% 20$ for $\% 20 \mathrm{a} \% 20$ UNEO.pdf $>$ (accessed 17 November 2018), 4-5.

12 UNEP is not an intergovernmental organization, but a subsidiary body of the United Nations General Assembly reporting through the United Nations Economic and Social Council (UNESC).

13 Biermann, supra nt 11.

14 Ibid.

15 Ibid. 
'Global environmental protection and sustainable development need a clearlyaudible voice at the United Nations. Therefore, in the short term ... it is important that cooperation among the various environmental organisations be significantly improved. In the medium-term this should lead to the creation of a global umbrella organisation for environmental issues, with the United Nations Environment Programme as a major pillar. ${ }^{16}$

Similar calls came subsequently from several leading politicians, ${ }^{17}$ academics, governments, expert commissions, as well as several international civil servants, and others. ${ }^{18}$ For example, in 1999, Renato Ruggiero, the Executive Director of the World Trade Organization (WTO), caused a stir by calling for a World Environment Organization as a counterbalance to the World Trade Organization - an unlikely proposal coming from a top-level bureaucrat (administrator) in view of the common preference of bureaucracies (organizations) to widen their own competences when in doubt. No doubt the debate on the need to integrate environmental standards into the World Trade Organization regime played a role here. ${ }^{19}$ In 1998 the French President Jacques Chirac joined the proponents of a world environment organisation by advocating a 'World Authority...as an impartial and indisputable global centre for the evaluation of our environment', ${ }^{20}$ and on 6 June 2000, the French environment minister, Dominique Voynet, announced that she would now use the French presidency of the European Union, started on 1 July 2000, to launch the idea of establishing an organisation mondiale de l'environnement. ${ }^{21}$

Chatham House (the Royal Institute of International Affairs), Ivanova, M; Draft Report: International Environmental Governance Reform: Options and Implications, September 2007, at <chathamhouse.org/sites /default/files/public/Research/Energy,\%20 Environment\%20and\%20 Development/260707ieg2.pdf> (accessed 17 November 2018); Helmut, K, Special Session United Nations General Assembly (23 June 1997); The Global Governance Project, Biermann, F and Bauer, S, Does Effective International Environmental Governance Require a World Environment Organization? The State of the Debate Prior to the Report of the High-Level Panel on Reforming the United Nations, Global Governance Working Paper No. 13, December 2004, at <glogov.org/images/doc/WP13.pdf> (accessed 17 November 2017), 11.

17 Jospin, L, "French Prime Minister Calls for Creation of New World Environment Organization" 25(5) International Environment Reporter (2002) 213; Newsweek, Gorbachev, M, The American and Russian People Don't Want a New Confrontation, April 27 2001; Speth, JG, "A Memorandum in Favor of a World Environment Organization" in Rechkemmer Baden-Baden, A, ed, UNEO-Towards an International Environment Organization (Nomos Verlagsgesellschaft 2005); Panitchpakdi, S, "The Evolving Multilateral Trade System in the New Millennium" 33(3) George Washington International Law Review (2001) 419-449.

18 Charnovitz, S, "A World Environment Organization" 27(2) Columbia Journal of Environmental Law (2002) 323, 323- 362; Charnovitz, S, "The Emergence of Democratic Participation in Global Governance" 10(1) Indiana Journal of Global Legal Studies (2003) 45,45- 77; Charnovitz, S, "Toward a World Environment Organization: Reflections upon a Vital Debate" in Biermann, F, and Bauer, S, eds, A World Environment Organization (Ashgate 2005); UN General Assembly, Report of the High-Level Panel on Financing for Development, 26 June 2001, (55th session) A/55/1000.

19 WZB, Biermann, F and Simonis, UE, Institutional Reform of International Environmental Policy: Advancing the Debate on a World Environment Organization, WZB Discussion Paper No. FS II 00- 401, Berlin, 2000, at <econstor.eu/bitstream/10419/49554/1/319098338.pdf> (accessed 17 November 2018), 4; Ruggiero, R, Address to the Royal Institute of International Affairs, A Global System for the Next Fifty Years (1998).

20 Biermann and Simonis, supra nt 19; Chirac, J, Congress of the World Conservation Union (3 November 1998).

21 Biermann, F, "The Case for a World Environment Organization" 42(9) Environment: Science and Policy for Sustainable Development (2000) 22, 22-31. 
This renewed political attention to global environmental governance reform among some governments spurred a vibrant debate and furthered academic input to the discourse that culminated at the 2002 World Summit on Sustainable Development in Johannesburg which helped to reinvigorate the debate. In an impassioned speech, then French President Jacques Chirac declared that the 'house is burning' and that a World Environment Organization is imperative for attending to the urgent ecological pressures on a global scale. ${ }^{22}$ The idea of a World Environment Organization is rooted in dissatisfaction with the current arrangements of international environmental governance and, more importantly, with the lack of effective environmental protection it has achieved so far. ${ }^{23}$

\section{Core Issues of Debate on the Need for a World Environment Organisation}

What are the main arguments put forward in support of a world environment organisation? Essentially, advocates of this new entity point to the following major shortcomings of the present state of global environmental governance: deficiencies in the coordination of distinct policy arenas, deficiencies in the process of capacity-building in developing countries, deficiencies in the implementation and further development of international environmental standards ${ }^{24}$ and absence of Democracy in International Environmental Governance.

\section{A. Better Coordination of Global Environmental Governance}

First, many observers claim that there is a coordination deficit between the international governance architecture that results in substantial costs and suboptimal policy outcomes. When the United Nations Environment Programme was set up in 1972, it was a comparatively independent player with a clearly defined work area. Since then, however, the increase in international environmental regimes has led to a considerable fragmentation of the system. ${ }^{25}$ According to the background paper for the 2010 consultative group, "There are now more than 500 international treaties and other agreements related to the environment, of which...302 date from the period between 1972 and the early 2000s'. ${ }^{26}$ Norms and standards in each issue area of environmental policy are set-up by separate legislative drafting parties of the environmental treaties-the conferences of the parties to the environmental treaties without much respect for repercussions and linkages with other policy fields. This situation is made worse by the organisational fragmentation of the various convention secretariats that have evolved

22 Ivanova, supra nt 16; Biermann and Bauer, supra nt 16.

23 Oberthür and Gehring, supra nt 2.

24 Development and Peace Foundation, Biermann, F and Simonis, UE, "A World Organization for Environment and Development: Functions, Opportunities, Issues" Policy Paper No. 9, Bonn, 1998; WZB, Simonis, UE, Global Environmental Governance: Speeding Up the Debate on a World Environment Organization, WZB Discussion Paper, No. FS II 02- 404, Berlin, 2002, at <econstor.eu/bitstream/10419/ 49568/1/351004734.pdf> (accessed 17 November 2018), 10; Haas, PM, Keohane, RO, and Levy, MA, eds., Institutions for the Earth: Sources of Effective International Environmental Protection (Harvard University Press 1993).

25 Biermann, supra nt 21; Biermann and Bauer, supra nt 18.

26 UNEP, Implementing the Clustering Strategy for Multilateral Environmental Agreements: A Framework. Background Paper By The Secretariat, UNEP/IGM/4/4 (2001); Perry, C, Strengthening International Environmental Governance: System-Wide Responses (International Peace Institute 2012), 5. 
into distinct medium-sized bureaucracies with strong centrifugal tendencies. For good reasons, there are no functionally different secretariats for the many conventions on labour standards, which are administered instead by a single specialized organisation, that is, the International Labour Organization (ILO) ${ }^{27}$

Streamlining environmental secretariats and negotiations into one body would especially increase the voice of the Global South - the "Developing World," "Developing Countries," "Less Developed Countries," "Less Developed Regions" (i.e., Africa, Latin America, and the developing countries in Asia, including the Middle East ${ }^{28}$ in global environmental negotiations. The current system of organisational fragmentation and inadequate coordination causes special problems for developing countries. Individual environmental agreements are negotiated in a variety of places, ranging, for example in ozone policy, from Vienna to Montreal, Helsinki, London, Nairobi, Copenhagen, Bangkok, Nairobi, Vienna, San José, Montreal, Cairo, Beijing and Ouagadougou. This nomadic nature of a 'travelling diplomatic circus' also characterises most sub-committees of environmental conventions. Developing countries lack the resources to attend all these meetings with a sufficient number of well-qualified diplomats and experts. ${ }^{29}$ The creation of a World Environment Organization could help developing countries to build up specialised 'environmental embassies' at the seat of the new organisation, which would reduce their costs and increase their negotiation skills and respective influence. ${ }^{30}$

More so, most specialised international organisations and bodies with some relation to environmental protection, such as the UN Food and Agriculture Organization (FAO) or the UN Educational, Scientific and Cultural Organization (UNESCO), have initiated environmental programs of their own over the years. Yet there is not much coordination among these organisations and their policies. If compared to national politics, the current international situation might come close to abolishing national environment ministries and transferring their programs and policies to the ministries of agriculture, industry, energy, economics, or a trade-a policy proposal that would not find many supporters in most countries. ${ }^{31}$

For global environmental policy, no central anchoring point exists that could compare to the World Health Organization (WHO), International Labour Organization (ILO), or World Trade Organization (WTO) in their respective fields, but there is an overlap in the functional areas of almost all bodies involved. An international centre with a clear strategy to ensure global environmental sustainable development thus seems to be the need of the hour. Just as within nation States, where environmental policy was institutionally strengthened through the introduction of independent environmental ministries, global environmental policies could be made stronger through an independent

$27 \quad$ Biermann, supra nt 21; Biermann and Simonis, supra nt 19.

28 See Mitlin, Diana, and Satterthwaite, David, Urban Poverty in the Global South: Scale and Nature (Routledge 2013), 13; See also Braveboy-Wagner, Jacqueline Anne, The Foreign Policies of the Global South: Rethinking Conceptual Frameworks (Lynne Rienner Publishers 2003), 11.

29 The Global Governance Project, Biermann, F, Global Environmental Governance: Conceptualization and Examples, Global Governance Working Paper No. 12, November 2004, at <glogov.org/images/doc/ WP12.pdf> (accessed 18 November 2018), 16; Rajan, MG, Global Environmental Politics: India and the North- South Politics of Global Environmental Issues (OUP 1997).

$30 \quad$ Biermann supra nt 29.

31 Biermann, supra nt 21. 
World Environment Organization that helps to contain the special interests of individual programs and organisations and to limit double work, overlap, and inconsistencies. ${ }^{32}$

\section{B. Promoting Capacity-building and Improved Financial and Technology Transfers in Developing Countries}

Secondly, supporters of a World Environment Organization argue that such a body could assist in the build-up of environmental capacities in developing countries. Capacitybuilding has become the key phrase of development cooperation and strengthening the capacity of developing countries, to deal with global and domestic environmental problems, has certainly become one of the most essential functions of global environmental regimes. ${ }^{33}$

Yet the current organisational setting for financial transfers to developing countries suffers from an adhocism and fragmentation that does not fully meet the requirements of transparency, efficiency, and participation of the parties involved. At present, most industrialised countries strive for a strengthening of the World Bank and its affiliate, the Global Environment Facility (GEF), to which they will likely wish to assign most of the future financial transfers (e.g., the phase out of persistent organic pollutants). Many developing countries, on the other hand, view this development with concern, given their perspective of the World Bank as a Western-dominated institution ruled by decision making procedures based on contributions. ${ }^{34}$

A potential solution would be to move the tasks of overseeing capacity-building and financial and technological assistance for global environmental policies to an independent body that is specially designed to account for the distinct character of developed-developing world relations in global environmental policy. Such a body could link the normative and technical aspects of financial and technological assistance and could be strong enough to overcome the fragmentation of the current system. Such a body could be a World Environment Organization. The organisation could be empowered to coordinate various financial mechanisms and to administer the funds of sectoral regimes in trust, including the Clean Development Mechanism and the emissions trading system under the Kyoto Protocol..$^{35}$

These responsibilities do not need to imply the setup of large new bureaucracies. Instead, a World Environment Organization could still make use of the extensive expertise of the World Bank or the United Nations Development Programme (UNDP), including their national representations in developing countries. However, by designating a World Environment Organization as the central authoritative body for the various

Ibid; Ivanova, M, "Global Governance in the 21st Century: Rethinking the Environmental Pillar" Stakeholder Forum Think Piece Series (2012) 6; Inge, Kaul, Public Goods: Taking the Concept to the 21st Century, 2001, at <http://www.yorku.ca/drache/talks/pdf/apd_kaulfin.pdf> (accessed 3 January 2019); Biermann, F, "Reforming Global Environmental Governance: From UNEP towards a World Environment Organization", in Swart, L and Perry, E, Global Environmental Governance. Perspectives on the Current Debate (Centre for UN Reform Education 2007), 105-108.

33 Biermann, supra nt 21; Keohane and Levy, supra nt 23; Connolly, B and Keohane, RO, "Institutions for Environmental Aid: Politics, Lessons, and Opportunities" 38(5) Environment: Science and Policy for Sustainable Development (1996), 12, 12-20, 39-42; Biermann, F, Global Environmental Policy between North and South: The New Bargaining Power of Developing Countries (Nomos 1998), 129-273; Ott, HE, "The Kyoto Protocol: Unfinished Business" 40(6) Environment: Science and Policy for Sustainable Development (1998), 16, 16-20, 41-45.

34 Biermann, supra nt 21.

35 Ibid. 
financial mechanisms and funds, the rights of developing countries over implementation could be strengthened without necessarily giving away advantages of the technical expertise and knowledge of existing organisations. ${ }^{36}$

Several years ago, the term capacity-building became a new catchword of development cooperation. Seen in empirical terms, the building of capacity, particularly in developing countries, is apt to be one of the essential functions of environmental regimes as well. Financial and technical cooperation on environmental problems nevertheless differs from traditional development cooperation: in particular the transfers effected by the Multilateral Ozone Fund or the Global Environment Facility (GEF) serve not only to build environmental capacities in the South, they also provide compensation for the full 'agreed' incremental costs incurred by developing countries in connection with global environmental policy, in accordance with the principle of the 1992 Rio conference on 'common but differentiated responsibilities and capabilities' of the parties. In this context, Hans Peter Schipulle, division head of the German Ministry for Economic Cooperation and Development, noted:

'Unlike classical development aid ..., these transfers, effected by environmental conventions, are obligations that are binding under international law.... If these obligations are not met by the industrialised countries, the developing countries can advance this as grounds for not meeting their own obligations, which in turn would harm the interests of the international community, i.e. including the industrialised countries. These stipulations become national law when the Convention is ratified and thus constitutes a new legal frame of reference for the cooperation with developing countries. ${ }^{37}$

\section{Development and Implementation of International Environmental Law}

Thirdly, supporters of a World Environment Organization argue that this organisation would be in a much better position to support regime-building processes, especially by initiating and preparing new treaties. Again, the International Labour Organization could serve as a model. The International Labour Organization has developed a comprehensive body of conventions that come close to a global labour code. In comparison, global environmental policy is far more disparate and cumbersome in its norm-setting processes. It is also riddled with various disputes among the United Nations specialised organisations regarding their competencies, with United Nations Environment Programme in its current setting being unable to adequately protect environmental interests. ${ }^{38}$ In addition to norm-setting, some argue that a World Environment Organization would also improve the overall implementation of international environmental standards. This responsibility does not necessarily require an organisation with 'sharp teeth', as some environmentalists recommend. Instead, the implementation of standards could already be facilitated, for example, by a common comprehensive reporting system on the state of the environment and on the state of implementation in different countries as well as by stronger efforts in raising public awareness. $^{39}$

The organisation should, for instance, have the right to collect, evaluate, and publish in a suitable form, information on the state of the environment and on the state of

Ibid.

Biermann and Simonis, supra nt 19.

Biermann, supra nt 21; Biermann, supra nt 32.

Biermann, supra nt 21. 
environmental policy in the United Nations member States, especially with regard to the international commitments assumed by individual States. Like most other specialised agencies of the United Nations, a World Environment Organization should therefore foster problem consciousness and seek to improve the state of the world's knowledge, including information on the earth system, existing environmental and development problems, as well as information on the state of implementation of international and national policy with a view to controlling global change. ${ }^{40}$

Clearly, the wheel does not need to be reinvented. Several environmental regimes already require their parties to report on specific policies. Specialised organisations, such as the World Meteorological Organization (WMO), the International Maritime Organization (IMO), or World Health Organization (WHO), collect and disseminate valuable knowledge and promote further research and the Commission on Sustainable Development makes important contributions by developing indicators for sustainable development. However, there remains a prevailing lack of comprehensive coordination, bundling, processing, and further channelling of this knowledge in a policy-oriented manner. The myriad contributions made by various international actors are clearly in need of a central anchoring point. This task could be much better carried out by an institutionally independent and sufficiently funded World Environment Organization that could then be entrusted, among others, with coordinating the reporting mechanisms of the various regimes ${ }^{41}$ and having more possibilities to support regime-building processes, particularly by initiating and preparing international treaties. ${ }^{42}$

\section{Promotion of Democracy in International Environmental Governance}

Fourthly, supporters of a World Environment Organization argue that global environmental governance can no longer be left in the hands of the rich countries alone; it has to include the Global South - the "Developing World," "Developing Countries," "Less Developed Countries," "Less Developed Regions" (i.e., Africa, Latin America, and the developing countries in Asia, including the Middle East) ${ }^{43}$ on the one hand, and civil society and local authorities on the other. Developing countries are marginalised in the decision-making process of global environmental governance. As Pierre Calame states, in international negotiations, only the agenda of rich countries is effectively taken into account. Poor countries have no choice but to have recourse to deliberations without real impact 'When the American president said at the 1992 Earth Summit that the American way of life was not negotiable, he nullified the negotiations. As long as what can be negotiated is decided only by the rich countries (for example, free movement of goods, yes, free movement of people, no; terms and conditions for the development of poor countries, yes, questioning rich countries' way of life, no; tradable permits for exchanges of carbon dioxide emissions, yes, property of natural resources, no; etc.), global environmental governance and its constraints will hardly be accepted. ${ }^{44}$

Another problem is the proliferation of complex international conferences that impose a heavy burden on negotiators and especially those from the Global South - the "Developing World," "Developing Countries," "Less Developed Countries," "Less Developed Regions" (i.e., Africa, Latin America, and the developing countries in Asia,

Biermann and Simonis, supra nt 19.

Biermann, supra nt 21.

Biermann and Simonis, supra nt 19.

Mitlin and Satterthwaite, supra nt 28; Braveboy-Wagner, supra nt 28.

Harada, supra nt 1. 
including the Middle East $)^{45}$ who are fewer, less specialised, and sometimes without access to proper translation. These organisational problems could be solved by topic clustering and an agenda-setting process determined through a vote of delegates from different regions. Participation of civil society is also increasingly important. The UN recognises that a 'global public policy network' is 'the most promising partnership in the age of globalisation.' At the global environmental governance level, representative democracy has reached its limits, notably because of a retreat of the state confronted by the power of the market and a lack of transparency. Citizens, NGOs, local authorities and the private sector need to be represented in an institution like the World Environment Organization. Legitimacy and transparency are at stake. In this regard, a World Environment Organization could provide a new model for a world organisation, promoting participative democracy. ${ }^{46}$

If we want environment consciousness to emerge in our society, the World Environment Organization has to be close to the citizen. Various means can be explored, including sending 'environment presenters' to schools, organising global conferences for citizens, public information campaigns, including citizens in the decision-making organs of the World Environment Organization, or creating a mechanism for the public to initiate a law- as can be found in the constitution project for the European Union, access environmental information, participate in environmental decision-making and access justice in environmental matters. Participation of NGOs in a more constructive and 'official' capacity could include granting access to NGOs to the Global Court for the Environment to denounce a treaty violation or intervene in judicial proceedings with an expanded amicus curiae status. Local authorities must not be forgotten. They are the central actors in implementation of sustainable development policies. ${ }^{47}$

Finally, the private sector must certainly play a part in the Global Environmental Governance. This can be achieved through a World Environment Organization that will bring in transnational companies as partners in global environmental governance. Multinational and national businesses have faced both internal and external pressures to become more environmentally friendly. Transnational corporations have long been regarded as perpetrators of international environmental degradation, moving investment and production to nations with the lowest environmental standards in search of higher profit margins. Nevertheless, since the 1990s, the United Nations (UN) and some civil society actors have changed tactics by engaging the private sector in partnerships to become part of the solution through voluntary corporate social responsibility. The private sector has also begun to respond with initiatives such as the World Business Council on Sustainable Development (WBCSD). ${ }^{48}$

At the same time, clean technologies are getting cheaper and it has been shown that carefully crafted, moderately demanding regulations can inspire businesses to create profitable, environmentally friendly innovations. ${ }^{49}$ However, more needs to be done.

$45 \quad$ Mitlin and Satterthwaite, supra nt 28; Braveboy-Wagner, supra nt 28.

$46 \quad$ Harada, supra nt 1.

47 Ibid.

48 See Najam, A, Papa, M and Taiyab, N, Global Environmental Governance: A Reform Agenda (International Institute for Sustainable Development 2006), 64; See Najam, A, "World Business Council on Sustainable Development: The Greening of Big Business or a Greenwash?” Yearbook of International Co-Operation on Environment and Development, 1999/2000 (Earthscan 1999), 65- 75.

49 Najam, Papa and Taiyab, supra nt 48; See Porter, M.E. and Van Der Linde, C., "Toward a new Conception of the Environment-Competitiveness Relationship." Journal of Economic Perspectives, (1995) 9(4), 97118. 
There is need for a World Environment Organization that will encourage various countries to formulate strong national regulatory frameworks that integrates environmental considerations into private sector investment since integration of environmental considerations into investment and development is crucial to effective environmental governance. ${ }^{50}$

\section{Models of Global Environmental Governance Reform}

Improving global environmental governance has been an issue of dynamic debate in academic and policy-making circles ever since environmental issues entered the international agenda in the 1970s. Since then, both environmental threats and international responses to them have increased in their number and complexity. The key challenge of global environmental governance has, however, remained the same: how to design an institutional framework (system) that would best protect the global environment.

\section{A. The Compliance Model}

The Compliance Model advocates creation of a body that could provide binding decisions to hold States and private actors accountable for non-compliance with Multilateral Environmental Agreements (MEAs) and resulting environmental damage. ${ }^{51}$ At the core of this proposal lies the recognition of the need for enforcement powers in the international system relating to the environment. Currently no environmental organisation possesses such authority or dispute settlement mechanism for environmental matters exists. ${ }^{52}$

Several potential bodies with such enforcement powers have been proposed. First, a World Environment Court ${ }^{53}$ with non-discretionary competence and broad legal access is envisioned as a permanent institution along the lines of the European Court of Human Rights, to ensure compliance with Multilateral Environmental Agreements and upholding the new right to a healthy environment. Until a World Environment Court is put in place, some of its supporters, which include legal experts and environmental protection agencies, propose a Permanent Court of Arbitration (PCA) which would be responsible for solving disputes linked to the environment. This court would be "a body which would be able to investigate all aspects of a case however overlapping or international they may be, ... which could go and question those really responsible behind their company fronts ..., would denounce governmental complacency ... which finally would be able to judge and also condemn those really responsible to restore the areas that are damaged and bring them back to a condition which is as close as possible to what they were initially". ${ }^{54}$

Najam, Papa and Taiyab, supra nt 48, 59.

Najam, Papa and Taiyab, supra nt 48, 17.

Ivanova, supra nt 16.

Najam, Papa and Taiyab, supra nt 48.

Le Prestre, P and Martimort-Asso, B, "Issues Raised by the International Environmental Governance System (Draft Version)"Institute for Sustainable Development and International Relations (IDDRI) Conference International Environmental Governance, Paris, March 2004, 39; see also petition launched by The Cousteau Team during the conference of the International Organization of Bio-Politics entitled "Resolving the Ecological Crisis: The Need to Create an International Criminal Court for the Environment", Athens, January 20-22nd, 2001, at <https://biopolitics.gr/biowp/wpcontent/uploads/2013/04/bionews26.pdf> (accessed 10 January 2019). 
Second, upgrading the Trusteeship Council ${ }^{55}$ to have authority over global commons and also represent interests of potential beneficiaries of the trust, especially future generations. Third, reinterpreting the mandate of the United Nations Security Council to include environmental security, having accommodated non-traditional threats such as, humanitarian emergencies and gross violations of human rights. ${ }^{56}$ Members of the United Nations Security Council declared in 1992 that 'peace and international security are not simply the result of the absence of wars and armed conflict. Other, nonmilitary threats to peace and international security are based on instability that exists in various economic, social, humanitarian and ecological domains'. Certain legal elements indicate that the mandate of the Security Council could be reinterpreted to include nontraditional aspects of threats to peace and security. Through this declaration, the members of the Security Council were indicating that non-compliance with Multilateral Environmental Agreements could be subject to Article 39 of the United Nations Charter and thereby give rise to sanctions against the countries concerned. ${ }^{57}$

Ideally, it is believed that the compliance model would solve the free rider problem, ensure care for the global commons, match judicial enforcement available elsewhere (especially in the World Trade Organization), enhance predictability and intergenerational concern of environmental law and directly impact compliance with Multilateral Environmental Agreements. In practice, States are reluctant to expose themselves to the compliance body's oversight and value judgments. There is a history of avoiding third party adjudication in international environmental law, inability to punish global commons' violators by exclusion or fines and low support for the exercise of 'enforcement' provisions. Finally, the probability of all States voluntarily accepting the compliance model is extremely low. ${ }^{58}$

\section{B. The New Agency Model}

The New Agency Model, also referred to by some authors as the Centralization Model, advocates for the creation of a new organisation outside of the United Nations Environment Programme with concentrated environmental responsibilities and the ability to steer United Nations agencies in relation to environmental issues. ${ }^{59}$ Proponents of this model call for a more fundamental reform to address the substantive and functional overlap between the many international institutions in global environmental governance. These advocates of a more centralised governance architecture call for the creation of a new organisation outside of the United Nations Environment Programme with concentrated environmental responsibilities and the ability to steer United Nations agencies in relation to environmental issues through the integration of several existing environmental and development programs and agencies into one all-encompassing

Najam, Papa and Taiyab, supra nt 48; Redgwell, C, "Reforming the United Nations Trusteeship Council" in Chambers, WB and Green, JF, eds, Reforming International Environmental Governance: From Institutional Limits to Innovative Reforms (United Nations University Press 2005), 178-203.

56 Najam, Papa and Taiyab, supra nt 48; Elliot, L, "Expanding the Mandate of the United Nations Security Council" in Chambers, WB and Green, JF, eds, Reforming International Environmental Governance: From Institutional Limits to Innovative Reforms (United Nations University Press 2005), 204226.

$57 \quad$ Le Prestre and Martimort-Asso, supra nt 54.

$58 \quad$ Najam, Papa and Taiyab, supra nt 48.

$59 \quad$ Ibid. 
World Environment Organization (WEO), ${ }^{60}$ a World Sustainable Development Organization (WSDO) ${ }^{61}$ or World Organization for Environment and Development. ${ }^{62}$

A similar proposal concerned the establishment of a Global Environmental Organization which - on the model of the World Trade Organization as the most important institution regulating world trade- having integrated diverse multilateral trade agreements, ${ }^{63}$ with broad rulemaking authority to address market failures and facilitate negotiation of international standards to be implemented by all countries - would serve as a forum for formulating and implementing global environmental policy; Global Environment Organization (GEO) would not only include the existing issue-specific international environmental agreements, it would also become the central institution concerned with financial and technological transfers. ${ }^{64}$

Other designs use the Global Environment Facility (GEF) as a role model ${ }^{65}$ for global environmental governance and advocate strengthening the role of GEF; strengthening the role of the United Nations Economic and Social Council (ECOSOC) and United Nations Commission on Sustainable Development (CSD) in discussing and overseeing system-wide coordination; propose an organisation for environmental bargaining $^{66}$ to trade environmental goods for money, or aim to reinforce G8 with leaderlevel G20 to serve as a platform for building the new agency.

According to some scholars, such a complete organisation could comprise of the United Nations Environment Programme, the hundreds of Multilateral Environmental Agreements (MEAs), the World Meteorological Organization (WMO), the Global Environment Facility (GEF), Commission on Sustainable Development (CSD), United Nations Development Programme (UNDP), the pollution control programs of the International Maritime Organization (IMO), the International Tropical Timber Organization, the fishery and forestry programs from the United Nations Food and Agriculture Organization (FAO), the Intergovernmental Panel on Climate Change (IPCC), the International Oceanographic Commission (IOC), the UN Inter-agency Committee on Sustainable Development (UNICSD), and many others. ${ }^{67}$

Proponents of this model are of the view that creation of a new agency is an opportunity to put together the best features of existing agencies and guide global environmental policy-making. Such an agency could address the problems of fragmentation and weakness of environmental governance within the United Nations system. However, putting all environmental agreements under one umbrella would be a major challenge, because the current system is strongly decentralised and individual

Charnovitz, S, "A World Environment Organization" 27(2) Columbia Journal of Environmental Law (2002), 323, 323-362.

61 Najam, Papa and Taiyab, supra nt 48; Glenn, JC and Gordon, T, 2050 Global Normative Scenarios (American Council for the United Nations University in cooperation with The Foundation for the Future 1999).

62 Biermann and Simonis, supra nt 19.

63 Charnovitz, supra nt 60.

64 WZB, Simonis, UE, Global environmental Problems - Searching for Adequate Solutions, WZB Discussion Paper, No. FS II 98-405, Berlin, 1998 at <bibliothek.wzb.eu/pdf/1998/ii98- 405.pdf> (accessed 18 November 2018) 31.

65 Najam, Papa and Taiyab, supra nt 48; Streck, C, "The Global Environment Facility - A Role Model for International Governance?" 1(2) Global Environmental Politics (2001), 71.

66 Najam, Papa and Taiyab, supra nt 48; Whalley, J and Zissimos, B, "What Could a World Environmental Organization Do?" 1(1) Global Environmental Politics (2001), 29-34.

67 Charnovitz, supra nt 60 . 
environmental entities strongly resist takeovers. ${ }^{68}$ Benefits of the new agency remain uncertain: it can potentially promote cooperation and increase States' environmental concern, but it risks being another big bureaucracy with modest civil society influence and no additional financial and technology transfer to developing countries. ${ }^{69}$

Germany has been the country seen as the main international proponent of a new United Nations specialised agency since Chancellor Kohl, in the mid-1990s, spoke out quite unexpectedly in favour of an 'Environmental Security Council', a proposal that was followed in 1997 by the call for a 'global umbrella organization for environmental issues, with the United Nations Environment Programme as its major pillar' and further pursued by Germany's Red-Green government. In a statement made on January 25, 1999, the environmental policy spokeswoman of the SPD Bundestag faction said:

\footnotetext{
"We need ... to focus the tangled and disjointed international organizations and programs. UNEP [UN Environment Programme], CSD [Commission on Sustainable Development], and UNDP [UN Development Programme] should be merged to form an organization for sustainable development. Close links to the World Bank, the International Monetary Fund, the World Trade Organization, and UNCTAD [UN Conference on Trade and Development] should be aimed for as a means of preventing environmental dumping and achieving an environmentally sound, sustainable development in line with Agenda $21 " .70$
}

The German Advisory Council on Global Change in 1996 likewise recommended an 'organization for sustainable development,' but without spelling out any specifics. ${ }^{71}$ In December 2000, the German Scientific Advisory Council on Global Change (WBGU) submitted its annual report, entitled 'World in Transition', new structures for global environment policy in which it recommended that the federal government should use the World Summit on Sustainable Development to launch structural reforms for the organisation of environmental policy in the United Nations system. The report proposed the creation of an 'earth alliance' based on three pillars: assessment, organisation and funding. The suggestion was made to strengthen United Nations Environment Programme in preparation for its transformation into a future World Environment Organization that would sit at the heart of this alliance. Having recommended the creation of an international environmental organisation as early as 1997, the German government, through the German Scientific Advisory Council on Global Change report, has since provided solid scientific evidence in support of its proposals and published a reference document on this question. ${ }^{72}$

\section{Upgrading United Nations Environment Programme (UNEP) Model}

68 Najam, Papa and Taiyab, supra nt 48, 27.

69 Najam, A, "The Case Against a New International Environmental Organization" 9(3) Global Governance: A Review of Multilateralism and International Organizations (2003), 367-384.

Simonis, supra nt 24.

71 German Advisory Council on Global Change (WGBU), World in Transition: Ways towards Global Environmental Solutions: Annual Report 1995 (Springer 1995).

72 Le Prestre and Martimort-Asso, supra nt 54; German Advisory Council on Global Change (WGBU), World in Transition: New Structures for Global Environment Policy, 1996. 
This model takes United Nations Environment Programme as a departure point for improving environmental governance and suggests upgrading it to a specialised agency to strengthen its status. This model is similar to the previous but distinct in that it seeks the strengthening of United Nations Environment Programme rather than its replacement by a different super-organisation. The United Nations Environment Programme itself has been both an active participant and a focus of the reform debate. ${ }^{73}$ It has faced significant challenges since its creation (limited legal mandate, lack of funds, location). The most broadly discussed proposal is upgrading the United Nations Environment Programme to a fully-fledged specialised agency ${ }^{74}$ so that it can adopt treaties, have its own budget and potentially use innovative financial mechanisms. Upgrading the United Nations Environment Programme to a specialised agency would strengthen its role as an 'anchor' institution ${ }^{75}$ for the global environment by drawing on its potential capability to function as information and capacity clearing-house and set broad policy guidelines for action within the Global Ministerial Environment Forum (GMEF).

Proponents of this approach have referred to the World Health Organization or the International Labour Organization as suitable models. Other agencies operating in the environmental field would neither be integrated into the new agency nor disbanded. ${ }^{76}$ It would leave substantively untouched the current institutional structure of international environmental governance. The established boundaries of the issue-areas governed by international regimes and their existing decision-making procedures would remain unchanged. ${ }^{77}$ The new agency in this model is expected to improve the facilitation of norm-building and norm-implementation processes. This strength would, in particular, derive from an enhanced mandate and better capabilities of the agency to build capacities in developing countries. This differs from United Nations Environment Programme's present 'catalytic' mandate that prevents the programme from engaging in project implementation. Furthermore, additional legal and political powers could come with the status of a United Nations special agency. For example, its governing body could approve by qualified majority vote certain regulations that could be binding, under certain conditions, on all members (comparable to the International Maritime Organization), or they could adopt drafts of legally binding treaties negotiated by subcommittees under its auspices (comparable to the International Labour Organization). Such powers would exceed those entrusted to United Nations Environment Programme, which cannot adopt legal instruments. ${ }^{78}$

Similarly, it has been suggested that United Nations Environment Programme could be upgraded into a decentralised United Nations Environment Organization (UNEO). ${ }^{79}$ The United Nations Environment Organization would have its own legal

Najam, Papa and Taiyab, supra nt 48; UNEP, supra nt 26.

Biermann, F, "The Rationale for a World Environment Organization" in Biermann, F and Bauer, S, eds, A World Environment Organization: Solution or Threat for Effective Environmental Governance? (Ashgate 2005), 117-144; UN General Assembly, Delivering as One: Report of the Secretary-General's High-Level Panel on UN System-Wide Coherence, (61st Session) A/61/583.

Ivanova, supra nt 7.

Biermann, supra nt 11.

Oberthür and Gehring, supra nt 2.

Biermann, supra nt 74.

Chatham House, Tarasofsky, RG, Report on Trade, Environment, and the WTO Dispute Settlement Mechanism, June 2005, at <ecologic.eu/sites/files/publication/2015/4_1800_cate_wto_dispute_ settlement.pdf> (accessed 18 November 2018); Tarasofsky, RG, "Strengthening International Environmental Governance by Strengthening UNEP" in Bradnee Chambers, W and Green, JF, eds, 
identity, and would comprise of a general assembly, executive structure and secretariat. It would incorporate United Nations Environment Programme and Global Ministerial Environment Forum, take up United Nations Environment Programme's mandate with respect to its normative function and serve as the authority for environment within the United Nations system. The main justification behind the proposal for a United Nations Environment Organization is the assumption that the United Nations Environment Programme's authority and mandate are inadequate for effective performance in addressing global environmental challenges. The core supposition is that the new status would accord the United Nations Environment Programme with greater visibility, status, independence, authority, finances and strengthen it 'so that it can fulfil its mandate as the principal agency for international environmental governance'.

Upgrading the United Nations Environment Programme to a United Nations Environment Organization requires less financial and diplomatic investment than adding a completely new organisation. While United Nations Environment Programme has a record of institutional success and learning, its potential to perform when given better legal status, more funds and more staff is promising. On the downside, focusing reform debate only on the United Nations Environment Programme distracts us from the broader institutional challenges, and it is not yet clear just how much of a difference specialised agency status will actually give. ${ }^{80}$

\section{Organizational Streamlining Model}

The Organizational Streamlining Model, also referred to by some authors as the Clustering Model, addresses the need for improved coordination and synergy among various entities within the system of global environmental governance. ${ }^{81}$ Clustering defines the grouping of several multilateral environmental agreements so as to make them more efficient and effective. ${ }^{82}$ Theoretically, the rationale for clustering is based on the notion that 'the environment' is too complex to be dealt with by one institution. The environmental agenda reflects multiple issues-from hazardous waste, to oceans pollution, to climate change, to biodiversity-that exhibit distinctively different problem structures. In practice, the rationale for clustering rests on the assumption that it would be easier to bring together the functions of several convention secretariats than establish a full-fledged international environmental organisation with similar powers. ${ }^{83}$

Improving coordination is a work in progress and an ongoing challenge within the United Nations system. Integrating environmental institutions into clusters (or clustering $)^{84}$ has been discussed as a way to achieve goals of environmental conventions,

Reforming International Environmental Governance: From Institutional Limits to Innovative Reforms (United Nations University Press 2005) 66-92.

80 Najam, A, "The Case against a New International Environmental Organization" 9(3) Global Governance (2003), 367-384.

$81 \quad$ Najam, Papa and Taiyab, supra nt 48.

82 Ivanova, supra nt 16; Von Moltke, K, REPORT: On Clustering International Environmental Agreements, (International Institute for Sustainable Development (IISD), June 2001), at <iisd.org/pdf/trade_ clustering_meas.pdf $>$ (accessed 18 November 2018), 3.

Ivanova, supra nt 16.

84 Najam, Papa and Taiyab, supra nt 48; Von Moltke, K, "Clustering Multilateral Environment Agreements as an Alternative to a World Environment Organization" in Biermann, F and Bauer, S, eds, A World Environment Organization: Solution or Threat for Effective Environmental Governance? (Ashgate 2005), 173-202; Najam, A, "A Tale of Three Cities: Developing Countries in Global Environmental Negotiations" in Churie, A, Kallhauge, GS and Correll, E, eds, Global Challenges: Furthering the Multilateral Process for Sustainable Development (Greanleaf 2005), 124-143; Oberthür, S, "Clustering of 
while also pursuing efficiency gains and improving coherence of environmental governance. Clusters can be issue/theme-based, function-based, functional/ organisational, geographically-based or administratively-based (co-location and 'merger' of secretariats). ${ }^{85}$ Another way to achieve synergy involves addressing duplication and overlaps by clarifying mandates of different entities, addressing their conflicting agendas and building upon their inter-linkages. ${ }^{86}$

Strategically, calls from the 24th Session of the UNEP GC/GMEF in 2007 called for specific approaches (not the consensus view) for clustering MEAs, including:

- Joint secretariat functions;

- Joint meetings of the bureaus within a cluster;

- Joint meetings of the heads of the scientific and technical committees within a cluster and, where relevant, between clusters;

- Appointment of an overall head of each cluster;

- Introduction of knowledge-management within and between clusters;

- Agreement on a methodological framework of indicators for measuring enforcement and compliance. ${ }^{87}$

While the large number of Multilateral Environmental Agreements is seen by some analysts as 'rooted in the fact that structural differences exist between many environmental problems, thus requiring separate institutional responses' ${ }^{88}$ the need for integration of related or overlapping international environmental regimes is undeniable. The current informal consultations on international environmental governance within the United Nations General Assembly have identified clustering of Multilateral Environmental Agreements as a major component of reform. The different proposals that exist identify six major thematic clusters subject areas: 1) conservation, 2) energy, climate change, and global atmosphere, 3) land conventions 4) chemicals and hazardous substances, ${ }^{89} 5$ ) marine and oceans pollution ${ }^{90}$ and 6) extractable resources.

\section{Sample of Proposals for Thematic Clustering ${ }^{91}$}

Multilateral Environmental Agreements: Potentials and Limitations in Chambers" in Bradnee Chambers, W and Green, JF, Reforming International Environmental Governance: From Institutional Limits to Innovative Reforms (United Nations University Press 2005), 40-65.

Najam, Papa and Taiyab, supra nt 48; Andresen, S, "Global Environmental Governance: UN Fragmentation and Co-ordination" in Schram Stokke, O and Thomessen, OB, eds, Yearbook of International Co-operation on Environment and Development (Earthscan Publications 2001), 19-26; United Nations University, REPORT: Inter-Linkages, Synergies and Co-ordination between Multilateral Environmental Agreements, July 1999, at <http://archive.unu.edu/inter-linkages/1999/ docs/UNUReport.PDF> (accessed 18 November 2018).

$86 \quad$ Ibid.

87 Prasad, DK, Quinn, M and Prasad, S, Sydney IEG Forum Project Team, Strengthening International Environmental Governance and Civil Society Leadership in Asia and the Pacific (The United Nations Environmental Programme and the University of New South Wales, December 2008), 24-25, at <https://digital.library.unt.edu/ark:/67531/metadc28509/m2/1/high_res_d/IEG-\%20Background paperApril2009-final.pdf $>$ (accessed 3 January 2019).

88 Ivanova, supra nt 16; Von Moltke, supra nt 82.

89 Perry, supra nt 26.

$90 \quad$ Ivanova, supra nt 16; Berruga and Maurer, supra nt 6.

91 Le Prestre and Martimort-Asso, supra nt 54, 36. 


\begin{tabular}{|c|c|}
\hline Theme & Relevant MEAs \\
\hline Conservation & $\begin{array}{l}\text { World heritage convention; Convention on biological diversity; } \\
\text { Convention on migratory species; Convention on international } \\
\text { trade in species of wild fauna and flora threatened with extinction } \\
\text { (CITES); African-Eurasian Migratory Water Bird Agreement } \\
\text { (AEWA); Agreement on the conservation of bats in Europe } \\
\text { (EUROBATS); Agreement on the conservation of seals in the } \\
\text { Wadden sea; Agreement on the conservation of small cetaceans in } \\
\text { the North and Baltic Seas (ASCOBANS); International coral reefs } \\
\text { initiative (ICRI); Lusaka agreement on concerted operations for } \\
\text { coercion targeting the illegal trade of wild fauna and flora; } \\
\text { Convention on wetlands of international importance, especially as } \\
\text { waterfowl habitat (RAMSAR). }\end{array}$ \\
\hline $\begin{array}{l}\text { Energy, Climate } \\
\text { Change and } \\
\text { Atmosphere }\end{array}$ & $\begin{array}{l}\text { United Nations framework convention on climate change; Vienna } \\
\text { convention on the ozone layer; Montreal protocol on the ozone } \\
\text { layer. }\end{array}$ \\
\hline Land & United Nations convention to combat desertification. \\
\hline $\begin{array}{l}\text { Chemicals and } \\
\text { Hazardous } \\
\text { Substances }\end{array}$ & $\begin{array}{l}\text { Bamako convention; Basel convention; Convention on civil } \\
\text { responsibilities for damage caused during the road, rail and internal } \\
\text { waterways transport of dangerous goods (CRTD); PIC convention; } \\
\text { Convention on the cross-border effects of industrial accidents; } \\
\text { Waigani convention; Stockholm convention on persistent organic } \\
\text { pollutants (POPS); Guidelines for the dissemination and use of } \\
\text { pesticides of the UN food and agriculture organisation (FAO). }\end{array}$ \\
\hline $\begin{array}{l}\text { Marine and } \\
\text { Oceans } \\
\text { Pollution }\end{array}$ & $\begin{array}{l}\text { Conventions of the international maritime organisation (IMO); } \\
\text { UNEP conventions on regional seas; Convention for the protection } \\
\text { of the marine environment in the North- East Atlantic (OSPAR); } \\
\text { Helsinki convention. }\end{array}$ \\
\hline $\begin{array}{l}\text { Extractable } \\
\text { Resources }\end{array}$ & $\begin{array}{l}\text { The different agreements on forestry; Public/private initiatives, } \\
\text { such as the forest stewardship council or the marine stewardship } \\
\text { council; Agreements on fisheries which have a link with } \\
\text { environmental impacts linked to agricultural activities. }\end{array}$ \\
\hline
\end{tabular}

Another six major clusters that have been identified are: biodiversity, oceans and seas, chemical and hazardous (dangerous) wastes, nuclear energy and weapon testing, climate and atmospheric change, and conventions linked to oceans and land. However, this proposal does not detail which Multilateral Environmental Agreements are linked to these problems. It suggests, also, that each cluster should be located in a country that already has a UN centre. ${ }^{92}$ In another document, the United Nations Environment Programme proposes clustering under four headings: sustainable development, biodiversity, chemical and hazardous waste and regional seas. ${ }^{93}$

92 Ibid.; See Dodds, "Felix, Inter-Linkages among Multilateral Environmental Agreements." Paper presented at the International Eminent Persons Meeting on Inter- linkages, United Nations University Centre, 3-4 September 2001, at <http://archive.unu.edu/inter-linkages/eminent/papers/WG2/ Dodds.pdf $>$ (accessed 10 January 2019).

93 Le Prestre and Martimort-Asso, supra nt 54; UNEP, supra nt 26. 
Functional clustering is based on the idea that existing Multilateral Environmental Agreements use institutions or depend on functions whose bottom-line objectives are similar, although adapted to each Multilateral Environmental Agreement. Four functions which can be clustered have been identified to include: 1) scientific assessment; 2) participation and transparency. The grouping of participation and transparency procedures of Multilateral Environmental Agreements could be based on model of the Aarhus convention; 3) implementation reports. The principle of clustering implementation support involves, for each country, publishing only one implementation report which would cover all the Multilateral Environmental Agreements; 4) conflict settlement. ${ }^{94}$

Regional clustering, on the basis of the principle that most environmental problems are not global in scale, with the exception of climate change, ozone depletion and persistent organic pollutants (POPs), some authors suggest that regional management of environmental issues would be more appropriate. It is indeed important to distinguish between global environmental problems (i.e. those which have impacts in different places around the globe) and those which affect more than one country (e.g. watershed management). Examples of regional clustering like this exist in Europe with the UN Economic Commission for Europe (UNECE). Regional clustering seeks to broaden the European example to apply it to different regions of the world. ${ }^{95}$

The core functions of Multilateral Environmental Agreements clusters will comprise streamlining activities and meetings, coordinating operations and budgeting, close tracking and active coordinating of funding, consolidating the implementation review by country or by issue and improving transparency and participation. Clustering the numerous international environmental agreements will therefore minimise institutional overlap and fragmentation in global environmental governance while avoiding the pitfalls of securing agreement for more radical institutional reform. ${ }^{96}$

This approach, however, cannot advance without leadership. Just like with the more ambitious proposals, it will require at least one of two necessary conditions - 1) individual governments ready to champion the establishment and maintenance of a cluster, and/or 2) coordinators and facilitators, be they existing institutions such as United Nations Environment Programme or newly established ones. Moreover, clustering is likely to be a necessary, but not sufficient, condition for more effective global environmental governance. ${ }^{97}$

Institutional fragmentation also has its benefits: ${ }^{98}$ it enhances visibility of environmental protection, advances specialisation and innovation and increases

Le Prestre and Martimort-Asso, supra nt 54; Von Moltke, K, "The Organization of the Impossible" 1(1) Global Environmental Politics (2001), 23.

95 Le Prestre and Martimort-Asso, supra nt 54; Kimball, LA, Reflections on International Institutions for Environment and Development, LEAD International Workshop, Bellagio Study and Conference Centre, 2000.

96 Ivanova, supra nt 16; Von Moltke, supra nt 84; E1-Ashry, M, Mainstreaming the Environment-Coherence among International Governance Systems, International Environmental Governance Conference, Institute of Sustainable Development and International Relations, Paris 2004; Von Moltke, K, Whither's MEAs: The Role of International Environmental Management in the Trade and Environment Agenda (International Institute for International Development, 2001).

97 Ivanova, supra nt 16.

98 Knigge, M, Herweg, J and Huberman, D, Geographical Aspects of International Environmental Governance: Illustrating Decentralization (Ecologic Institute for International and European Environmental Policy 2005); United Nations University, Dodds, SEH, Chambers, WB and Kanie, N, eds, REPORT: 
commitment of States that host international environmental conventions secretariats. ${ }^{99}$ However, fragmentation has many disadvantages including institutional overlap, high financial and administrative costs, and increased reporting demands felt especially in developing countries. The effect of these disadvantages is reduction of state participation and decrease in implementation of environmental law. All organisational streamlining proposals need to be well designed in order to contribute to the solution of the problem. Otherwise they may worsen the current situation. ${ }^{100}$

\section{E. Multiple Actors Model}

The Multiple Actors Model argues that the system of governance comprises multiple actors whose actions need to be mutually reinforcing and better coordinated. Without better integration of these multiple actors, organisational rearrangement cannot resolve institutional problems. Multiplicity of actors and interactions form a multidimensional 'system' of global environmental governance. ${ }^{101}$ It includes States, international environmental organisations, related international organisations, civil society organisations, and public concern and action. Focus on organisations as a single dimension of governance distracts attention from the fact that institutional will is required to affect decision-making procedures and change institutional boundaries. ${ }^{102}$

The first reform proposal is to integrate environment into the larger context of sustainable development and to allow multiple organisations to flourish but create venues for these organisations to interact and 'transact.' According to the supporters of this model, preferring environmental to sustainable development governance may result in further marginalisation of environmental problems on the international agenda, alienation of developing countries, and continuing regime clashes between environment and other relevant international regimes. Supporters of this model are of the view that a General Agreement on Environment and Development should be negotiated to codify universally accepted sustainable development principles and serve as an umbrella for existing Multilateral Environmental Agreements. ${ }^{103}$

The second reform proposal is to create multiple channels of implementation. The quality of global environmental governance will be increasingly determined by the interaction among various entities in implementation and the ability of the system to facilitate their interaction, e.g., through Global Public Policy Networks. ${ }^{104}$ Both policy makers and academics argue that too many constraints and mechanisms inhibit performance of the Global Environmental Governance (GEG) system. The

International Sustainable Development Governance: The Question of Reform: Key Issues and Proposals: Preliminary Findings, United Nations University Institute of Advanced Studies, Tokyo, 2002.

99 Najam, A, Christopoulou, I and Moomaw, B, "The Emergent System of Global Environmental Governance" 4(4) Global Environmental Politics (2004), 23, 23-35; Najam, supra nt 84; Knigge, Herweg and Huberman supra nt 98.

100 Najam, Papa and Taiyab, supra nt 48, 20.

101 Ibid.; Sanwal, M, "Trends in Global Environmental Governance: The Emergence of a Mutual Supportiveness Approach to Achieve Sustainable Development" 4(4) Global Environmental Politics, (2004), 16, 16-22; Najam, Christopoulou and Moomaw, supra nt 99.

102 Najam, Papa and Taiyab, supra nt 48; Oberthür, S and Gehring, T, "Reforming International Environmental Governance: An Institutional Perspective on Proposals for a World Environment Organization" in Biermann, F and Bauer, S, eds, A World Environment Organization: Solution or Threat for Effective International Environmental Governance? (Ashgate 2005), 205-234.

103 Najam, Papa and Taiyab, supra nt 48; Najam, A, "Financing Sustainable Development: Crises of Legitimacy" 2(2) Progress in Development Studies (2002), 153, 153-160.

104 Najam, Christopoulou and Moomaw, supra nt 99. 
establishment of public policy networks, both bureaucratic and scientific, are proposed as viable tools for decision-making and delivery of results. ${ }^{105}$ These networks would incorporate the public, government, and civil society groups in order to find holistic solutions to complex problems. ${ }^{106}$ Streck asserts that in order for Global Public Policy Networks (GPPN) to be successful, they must embody a number of qualities. For instance, there is a need for a diversity of cultures and stakeholders. The qualities of openness, flexibility, and efficiency in issues identification, outlining visions and options, creating action plans and launching a concrete plan for their attainment are also central to successful GPPNs. Functions of a new global public policy network might include:

- Agenda setting;

- Standard setting;

- Generating and disseminating knowledge;

- Balancing institutional effectiveness;

- Providing innovative implementation mechanisms. ${ }^{107}$

For example, in 2008 at the Commission on Sustainable Development (CSD), a global public policy networks (GPPN) brought together the UN, governments, and major groups for discussions on water and water management. This particular network was managed by the Stockholm International Water Institute and Stakeholder Forum, and had on its steering committee UN Water, five governments-two of which represent developing countries-from the CSD Bureau and stakeholders. It played a significant role in helping governments prepare for the CSD discussion on water and sanitation. ${ }^{108}$

Another reform proposal under this model is the demand for a Global Environmental Mechanism (GEM). Advocates of this new system state that 'no single bureaucratic structure can build an internal organisation with the requisite knowledge and expertise to address the wide ranging, dynamic, and interconnected problems we now face'. ${ }^{109}$ The suggested core capacities of a new GEM would be: 1) The provision of adequate information and analysis to characterise problems, track trends, and identify interests; 2) Creation of a 'policy space' for environmental negotiation and bargaining, sustained build-up of capacity for addressing issues of agreed-upon concern and significance. In relation to the proposed work functions that a GEM would possess, a number have been emphasised including:

- Problem Identification and definition;

Prasad, DK, Quinn, M and Prasad, S, supra nt 87; Speth, GJ and Haas, P, Global Environmental Governance: Foundations of Contemporary Environmental Study (Island Press 2006); Jan, MW, Thorsten, B and Charlotte, S, "Partnerships and Networks in Global Environmental Governance: Moving to the Next Stage" in Ulrich, P, James, R and Ernst, UVW, eds, Governance and Sustainability: New Challenges for States, Companies and Civil Society (Greenleaf Publishing Limited 2005), 143.

106 Prasad, DK, Quinn, M and Prasad, S, supra nt 87; Streck, C, "Global Public Policy Networks as Coalitions for Change" in Esty and Ivanova, M, eds, Global Environmental Governance: Options and Opportunities (Yale School of Forestry and Environmental Studies, 2002); Howlett, M, "Managing the 'Hollow State': Procedural Policy Instruments and Modern Governance" 43(4) Canadian Public Administration (2000), 412-431; Jan, Thorsten and Charlotte, supra nt 101.

107 Streck, supra nt 106.

108 Prasad, DK, Quinn, M and Prasad, S, supra nt 87.

109 Ibid., 23-24; Esty, D and Ivanova, M, "Environment: The Path of Global Environmental Governance" in Ayre, G and Callaway, R, eds, Governance for Sustainable Development: A Foundation for the Future (Earthscan 2005), 65. 
- Analysis and option evaluation;

- Policy discussion and coordination;

- Financing and support for action;

- Outreach and legitimacy. ${ }^{110}$

Additionally, Esty and Ivanova have pointed out that a Global Environment Mechanism might contain the following elements:

- A Data Collection Mechanism, ensuring the availability of reliable data of high quality and comparability, developing indicators and benchmarks, and publishing State of the Global Environment reports;

- A Compliance Monitoring and Reporting Mechanism, providing a repository for information on compliance with agreements and established norms, and a continuous and transparent reporting effort;

- A Scientific Assessment and Knowledge Networking Mechanism, drawing on basic research on environmental processes and trends, long-term forecasting, and early warnings of environmental risks;

- A Bargaining and Trade-offs Mechanism, facilitating the internalisation of externalities through exchanges of commitments on various environmental issues (forest cover, biodiversity protection, species management, etc.) in return for cash or policy change (market access);

- A Rulemaking Mechanism for the global commons, establishing policy guidelines and international norms on protection of shared natural resources such the atmosphere and oceans;

- A Civil Society Participation Mechanism, providing a business and NGO forum for direct participation in problem identification and policy analysis;

- A Financing Mechanism, for global-scale issues mobilising both public and private resources to provide structured financial assistance to developing countries and transition economies;

- A Technology Transfer Mechanism, promoting the adoption of best options suited to national conditions and encouraging innovative local solutions;

- A Dispute Settlement Mechanism, with agreed procedures and rules to promote conflict resolution between environmental agreements and vis-à-vis other global governance regimes in an equitable manner;

- An Implementation Strategies Mechanism, ensuring coordination with institutions with primary implementation responsibility (such as national governments, UNDP, World Bank, business, civil society organisations) and providing a database of best practices. ${ }^{111}$

The Multiple Actors Model adopts a broad definition of the problem of global environmental governance. Accordingly, the solutions proposed are broad and offer directions the system should follow, rather than specific organisational improvements. While organisational thinking leaves an illusion of control over governance, systems thinking acknowledge the messiness and uncertainty of the system. The complexity of

110 Prasad, DK, Quinn, M and Prasad, S, supra nt 87; Esty and Ivanova, supra nt 7, 4-6.

111 Esty, D and Ivanova, M, "Revitalizing Global Environmental Governance: A Function-Driven Approach" in Esty, D and Ivanova, M, eds, Global Environmental Governance: Options and Opportunities (Yale School of Forestry \& Environmental Studies 2002). 
today's environmental threats like climate change and responses to them prove that multiple channels of implementation naturally emerge but can lack direction if one is not provided by the system. Whether the system is mature enough to reverse environmental degradation via strategic directions and normative guidance remains to be seen ${ }^{112}$ For example, while useful and popular, the Global Public Policy Networks are also widely considered complementary, rather than exclusive, solutions. As noted at the July 2007 Chatham House Workshop, 'effective and efficient operation of public policy networks requires the existence of an institutional hub'. ${ }^{113}$

\section{Argument against a World Environment Organization}

Critics of a new World Environment Organization argues that advocates of a central environmental authority divert attention from more pressing problems and fail to acknowledge that centralising institutional structures is an anachronistic paradigm. ${ }^{114}$ They argue in favour of decentralised institutional clusters to deal with diverse sets of environmental issues rather than entrusting all problems to one central organisation. ${ }^{115}$ They are of the view that, although a large World Environment Organization would have some compelling logic behind it, such a massive reorganisation is inconceivable. Yet even if it could be done, there are strong arguments against it. One problem is that environmental issues are often diverse from each other and the plenitude of issues might not coexist well. ${ }^{116}$ Thus, benefits from an integration of issue-areas as advocated by the New Agency/Centralization Model are limited because international environmental governance is predominantly about the preservation of collective goods rather than club goods. Free international trade for instance, has the properties of a club good that is accessible only to the members of the club. ${ }^{117}$

Thus, States are effectively excluded from reaping the benefits of a liberalised world trade unless they open their own markets. ${ }^{118}$ In contrast, environmental protection is frequently a collective good. It will be difficult to prevent a State from taking a free ride if it cannot be excluded from enjoying the collective good of environmental protection. Countries refusing to cooperate to protect the ozone layer cannot be excluded from the benefits of a stabilised ozone layer. Accordingly, States have an incentive to stay out of costly cooperation ${ }^{119}$ that will increase with every issue that a country opposes. Thus, a World Environment Organization modelled for instance, after the World Trade Organization being one of the proposed options of the New Agency/Centralization

Najam, Papa and Taiyab, supra nt 48; Najam, supra nt 103.

Hoare, A and Tarasofsky, R, International Environmental Governance: Report of the Chatham House Workshop, Chatham House, July 2007.

Oberthür and Gehring, supra nt 102.

Von Moltke, K, "Clustering Multilateral Environment Agreements as an Alternative to a World Environment Organization" in Biermann, F and Bauer, S, eds, A World Environment Organization: Solution or Threat for Effective Environmental Governance? (Ashgate 2005), 173-202; Najam, A, "Neither Necessary, Nor Sufficient: Why Organizational Tinkering Will Not Improve Environmental Governance" in Biermann, F and Bauer, S, eds, A World Environment Organization: Solution or Threat for Effective Environmental Governance? (Ashgate 2005), 223-242.

Charnovitz, supra nt 60.

Oberthür and Gehring, supra nt 2; Cornes, R and Sandler, T, The Theory of Externalities, Public Goods and Club Goods (2nd ed, CUP 1999).

Oberthür and Gehring, supra nt 2; Hoekman, BM and Kostecki, MM, The Political Economy of the World Trading System: From GATT to WTO (OUP 1995), 27-30.

Oberthür and Gehring supra nt 2; Olson, M, The Logic of Collective Action: Public Goods and the Theory of Groups (Harvard University Press 1965). 
Model threatens to undermine its own basis and endangers gains so far realised through sector-specific cooperation in international environmental regimes. ${ }^{120}$

Likewise, issue-linkage through integration of issue-areas does not help pressure non-cooperating States and enforce implementation of international environmental commitments. Proponents of environmental protection cannot credibly threaten to make protection of the ozone layer conditional on United States acceptance of controls on greenhouse gases, because realising this threat would harm themselves at least as much as the opponent. The same logic applies to the enforcement of obligations. While for example, disregard of obligations within World Trade Organization may be effectively prosecuted by excluding non-complying countries from benefits in any suitable area of international trade, this threat is usually not available in environmental institutions: a country's non-compliance with obligations to conserve biological diversity cannot usefully be responded to by not complying with commitments to protect the ozone layer.

In several respects, a World Trade Organization-like World Environment Organization does not change the status quo at all. It is unlikely that it is apt to mobilise the additional financial resources needed to reinforce the capacity of developing countries to implement international obligations and develop effective environmental policies. In other words, there is no indication that industrialised countries might be more willing to provide additional financial resources to assist implementation of international environmental commitments in developing countries if issue-areas were integrated. ${ }^{121}$

Another problem is that the resulting organisation would cut a huge swath through domestic policy, and no government would be comfortable giving any World Environment Organization executive that much responsibility. In pointing out why a broad World Environment Organization would be impossible, opponents of a World Environment Organization argued that no major government has an environmental ministry as broad as integrating all its environmental issues and functions as a fully centralised World Environment Organization contemplates. In their view, if governments have not deemed it advisable to amalgamate environmental functions at the national level, but have maintained separate national agencies with environmental functions, why should one assume it would be advantageous at the international level? ${ }^{122}$

The fallacy of full centralisation according to critics of a World Environment Organization can also be seen by recalling that even the non-environmental agencies will need environmental programs, staff, and offices. The World Bank, the World Trade Organization, International Labour Organization, World Health Organization, Food and Agriculture Organization, United Nations Educational, Scientific and Cultural Organization, the United Nations Conference and Trade and Development, the International Atomic Energy Agency and the Organization for Economic Co-operation and Development all have environmental components, and properly so. Thus, critics of a World Environment Organization are of the view that the mainstreaming of environment into all agencies is one of the successes of modern environmental policy, even if these environmental components are inadequate. The existence of such environmental offices is the means that organisations use to interface with related issues. The fact that there

120 Oberthür and Gehring, supra nt 2.

121 Ibid.; Oberthür, S and Gehring, T, Institutional Interaction: Toward a Systematic Analysis, International Studies Association Annual Convention, Portland, 26 February - 1 March 2003.

122 Charnovitz, supra nt 60; Juma, C, "The Perils of Centralizing Global Environmental Governance" Environment Matters (2000), 13, 15; Financial Times, Juma, C, Stunting Green Progress, 6 July 2000; Financial Times, Esty, DC, Global Environment Agency Will Take Pressure off WTO, 13 July 2000. 
may be a dozen or more international offices addressing climate change is not symptomatic of disorganisation. Rather these offices exemplify recognition that responding to global warming will require a multifaceted effort. ${ }^{123}$

That a fully centralised World Environment Organization is inconceivable should not come as a surprise because no other regime is fully centralised either. The World Trade Organization may be the core of the trade regime, but many trade agencies and bodies of law lie outside of it, such as United Nations Educational, Scientific and Cultural Organization, the United Nations Conference and Trade and Development (UNCTAD), the International Trade Centre, the trade directorate of the Organization for Economic Co-operation and Development (OECD), the United Nations Convention on Contracts for the International Sale of Goods, the United Nations Commission on International Trade Law, and various agreements on trade in food, endangered species, hazardous waste, military goods, etc. The World Health Organization may be the core of the health regime, but many health agencies and bodies of law lay outside of it, such as the United Nations Population Fund, the Joint UN Program on HIV/AIDS, the United Nations International Drug Control Programme, the International Consultative Group on Food Irradiation, and numerous International Labour Organization conventions. ${ }^{124}$

The main advocates of the World Environment Organization target the centralisation of environmental agencies and functions-the bringing of Multilateral Environmental Agreements and their associated functions under one umbrella organisation. Can we really expect a World Environment Organization to lead to higher value outputs in environmental governance? Reducing the excessive fragmentation in the environmental regime would seem, almost necessarily, to be beneficial. Yet fragmentation also has its good side. According to recent management research, innovation proceeds most rapidly under conditions of some optimal, intermediate degree of fragmentation. ${ }^{125}$ Thus, the institutional fragmentation of international environmental governance indicates strength rather than a weakness of environmental cooperation. The multitude of well-functioning environmental institutions indicates that actors have, for the most part, succeeded in defining viable issue-areas in international environmental governance and that an integration of issue-areas is not required in order to ensure mutual benefits of the parties involved. ${ }^{126}$ Since a high capacity for innovation may be the most distinguishing feature of the environment regime and a key source of its successes, one needs to be careful about undertaking a reorganisation that would reduce fragmentation, and hence innovation. One reason why some fragmentation is good for innovation is that fragmented entities compete with each other. The environment regime has surely benefited from diversity among the entities that do environmental work. ${ }^{127}$

A World Environment Organization following the Upgrading United Nations Environment Programme/United Nations Model would not significantly affect the governance capacity of institutions making international environmental policy. The currently separate environmental issue-areas would not be integrated, because the sectorspecific decision-making processes would remain in place. The participating actors would

Charnovitz, supra nt 60; Szasz, PC, "Restructuring the International Organizational Framework" in Weiss, EB, ed, Environmental Change and International Law: New Challenges and Dimensions (United Nations University Press 1992), 340, 355, 383.

Ibid.

125 Ibid.; Wall Street Journal, Diamond, J, The Ideal Form of Organization, 12 December 2000.

126 Oberthür and Gehring, supra nt 2.

127 Charnovitz, supra nt 60. 
continue to determine their preferences in relation to those issues falling inside the respective issue-areas, while ignoring other issues. Opportunities for cooperation would continue to arise exclusively as a result of these sector-specific preferences. If decisionmaking proceeds separately for each issue-area, although within the framework of an umbrella organisation, negotiators would not receive additional incentives to coordinate their sector-specific activities and to look for possible issue-linkages or for package deals cutting across the boundaries of established issue-areas.

Those negotiating climate changes would continue to focus on measures to stabilise the global climate, while members of the regime on biological diversity would continue to concentrate on preserving biodiversity. Whereas an exchange of information may be facilitated, resulting tensions between both regimes regarding forestry activities (maximisation of carbon sequestration versus conservation of biological diversity) would persist. Likewise, the mechanisms for supervising and facilitating implementation, such as non-compliance procedures and other functional bodies, would not significantly change, because they would remain organised by sector. A World Environment Organization constructed after the United Nations model could be expected to realise limited efficiency gains at best, but it would not make a significant contribution to the solution of problems of international environmental governance related to decisionmaking, implementation and coordination. A certain potential for combining certain auxiliary functions of environmental regimes (e.g., reporting, review of implementation) might exist, but gains would be moderate. The bigger problems of international environmental governance could not be solved because this World Environment Organization would not significantly change the delimitation of existing issue-areas or the design of the related decision-making processes. The creation of an umbrella organisation would thus largely be a matter of symbolic politics. ${ }^{128}$

More so, it is argued that the grouping of several multilateral environmental agreements into thematic clusters as suggested by the Organizational Streamlining/Clustering Model is important but only part of the solution. Clustering of some of the hundreds of multilateral environmental agreements has been proposed to address the apparent coordination problems in global environmental governance. Clustering could involve the relocation of treaty secretariats, including the streamlining of administrative services, as well as the co-scheduling of conferences of the parties to related conventions (for instance through back-to-back meetings), the clustering of environmental reporting and information generation and distribution, for example in uniform reports, scientific assessments and clearinghouses or the synchronisation of the meetings of treaty bodies. ${ }^{129}$

Clustering can only be a first step for a larger reform effort. There are so many different levels of clusters for convention-related activities necessary that separate clusters at each of these levels would not solve the existing coordination problems, but could even exacerbate them. For example, convention-related efforts need to be clustered, at one level, according to the environmental medium that is to be protected. Examples would be those agreements that protect the atmosphere or those that protect the marine environment. Such form of clustering is required in particular regarding scientific research and assessment, since the behaviour, transportation and effects of greenhouse 
gases, ozone-depleting substances and persistent organic pollutants are the subject of similar and related scientific efforts and models. ${ }^{130}$

At another level, however, convention-related efforts need to be clustered according to the human activity at the root of the problem, for example intensive agriculture, transportation, or industrial production. Yet such activity-based clusters would require a different cut. The climate convention, for example, would need to be clustered, for one, with the agreements affecting transportation (together with marine pollution treaties, for example); with agreements regulating industrial production (e.g., jointly with the agreements on ozone-depleting and persistent organic pollutants); with deforestation-related conventions, such as the biodiversity convention and with soilrelated conventions, like the desertification convention. Furthermore, clusters are needed to address common problems related to the environmental policy instrument chosen. One example would be a cluster of agreements that require restrictions in trade, for example trade in ozone-depleting substances, in endangered species, in persistent organic pollutants, in hazardous waste, or in genetically modified organisms. The practical implications could be joint programs for the training of custom officials or joint information-sharing mechanisms. ${ }^{131}$

Another area of clustering would be capacity-building in the Global South - the "Developing World," "Developing Countries," "Less Developed Countries," "Less Developed Regions" (i.e., Africa, Latin America, and the developing countries in Asia, including the Middle East). ${ }^{132}$ Many environmental agreements have their own provisions on capacity-building, or even their own funding mechanism for these activities (e.g., the Montreal Protocol), without necessarily much coordination. This would, again, call for a different set of clusters. Another kind of clustering would be the regional clusters. To cluster environmental conventions according to all these levels could significantly increase the coordination deficits of the current system, instead of reducing them. ${ }^{133}$

\section{Conclusion and Recommendations}

No crisis in world history has so clearly demonstrated the need for closer cooperation and mutual collaboration among States and increasing interdependence of governments and other stakeholders as the contemporary global environmental crisis. The pressures wielded by the dynamic forces of socio-economic development and technological advancement have radically transformed the global environment and the ecological balance of Earth as never before. ${ }^{134}$ The complex nature of environmental problems experienced at any given political jurisdiction frequently have their origins at locations other than where their far-reaching consequences are most seriously felt. ${ }^{135}$ In terms of jurisdictions, the legal boundaries of sovereign States do not coincide with the limits of

130 Ibid.

Ibid.

Mitlin and Satterthwaite, supra nt 28; Braveboy-Wagner, supra nt 28.

Biermann, supra nt 33.

134 Ambalam, K, "Challenges of Compliance with Multilateral Environmental Agreements: The Case of the United Nations Convention to Combat Desertification in Africa" 5(2) Journal of Sustainable Development Studies (2014), 145-168, 147-148; UNEP, supra nt 2.

135 Ibid.; Caldwell, LK, "Management of Resources and the Environment: A Problem in Administrative Coordination" 38(2) International Review of Administrative Sciences (1972), 115-127. 
the ecological systems which sustain them. ${ }^{136}$ The environmental harm caused by a sovereign State is a threat to all nations, irrespective of their background of socioeconomic development and the nature and availability of physical and natural resources. Now there is no exit option for the governments since the complex and highly interdependent ecological challenges binds all nations and creates a new level of dependence among nation States. ${ }^{137}$

However, collective action in response to global environmental challenges continues to fall short of needs and expectations. The integrated and interdependent nature of the current set of environmental challenges contrasts sharply with the fragmented and uncoordinated nature of the institutions we rely upon for solutions. We need an approach that acknowledges the diversity and dynamism of the environmental challenge and recognises the need for specialised responses. We need an environmental organisation with the resources and authority to succeed at leading and coordinating international environmental governance; a much stronger global voice and conscience for the global environment. ${ }^{138}$

The systemic problems of international environmental governance have remained outside the political debates because of both ideological and technical difficulties. Ideologically, nation States give priority to national sovereignty over the common planetary interest and developing countries are still fearful that international environmental agreements are a front for an agenda designed to stunt their economic growth. As the G-77 and China's statement in the contemporary reform process contends, 'Promotion of environmental protection alone in developing countries is not a priority as it raises obstacles to the use of limited resources for economic development'. Developing countries thus insist that international environmental governance reform negotiations be firmly grounded in a sustainable development framework. ${ }^{139}$

Specifically, developing countries have clearly identified principles which, according to them, should be present at any discussion of international environmental governance reform. They include:

- the context must be one of sustainable development;

- the principle of common but differentiated responsibilities must remain a central element of international cooperation in the environmental field;

- fairness: any reform must ensure the real participation of the developing countries in the governance system (in the management of funds, for example);

- the reform of governance must promote capacity-building (so as to facilitate the implementation of agreements and the development of national policies). ${ }^{140}$

Technically, developing countries claim that new and additional financial resources are necessary for them to be able to take on the new environmental agenda, that technology transfer is critical to their ability to leapfrog over traditional industrialisation methods, and that greater capacity-institutional, technological, and

Ambalam, supra nt 134; Imber, MF "The Environment and the United Nations" in Vogler, J and Imber, MF, eds, The Environment and International Relations (Routledge 1996), 149-165.

137 Ambalam, supra nt 134; Biermann, F and Dingwerth, K, "Global Environmental Change and the Nation State" 4(1) Global Environmental Politics (2004), 1-22.

Ivanova, supra nt 7, 14.

Ibid.

Le Prestre and Martimort-Asso, supra nt 54. 
human-would be indispensable to integrating environmental concerns into development priorities. Industrialised countries, on the other hand, demand accountability for any funding as well as monitoring, reporting and verification procedures for environmental actions. ${ }^{141}$

Given the current state of environmental politics, creating any form of a new agency might appear unrealistic to some. Yet two decades ago, the establishment of an international criminal court or a world trade organisation appeared unrealistic, too. It is time again to demand the impossible. ${ }^{142}$ In sum, creating a World Environment Organization would pave the way for the elevation of environmental policies on the agenda of governments, international organisations and private organisations; it could assist in developing the capacities for environmental policy in African, Asian and Latin American countries; and it would improve the institutional environment for the negotiation of new conventions and action programmes as well as for the implementation and coordination of existing ones. ${ }^{143}$

The resistance to any streamlining effort by interested actors-including the heads of the various convention secretariats, who are likely to lose influence-is a practical problem rather than a theoretical obstacle to delineating a mandate for a World Environment Organization. A World Environment Organization would not solve all problems, neither of industrialised countries nor of developing countries. But it would be an important institutional step in humankind's efforts to both equitably and effectively manage planet Earth. ${ }^{144}$

This paper, therefore, supports the view that a World Environment Organization should be established with, among other things, the mandate of achieving a comprehensive and systematic global environmental policy. This will help cure the main inadequacies of the current condition of global environmental governance which includes: deficiencies in the coordination of distinct policy arenas (fields), deficiencies in the process of capacity-building in developing countries, and deficiencies in the implementation and further development of international environmental standards. However, as with all international organisations, the establishment of a World Environment Organization would need to be approved and adopted at a diplomatic convention, which would determine the Organization's mandate, financial plan (budget) and other procedural matters.

Further, the proposed World Environment Organization should be: strongly grounded in the context of sustainable development framework by ensuring that nation's industrial and technological development to improve the national economy does not compromise the social and ecological environment. Thus, the proposed World Environment Organization must seek to help nations strike a balance between their economic development and environmental sustainability and protection; the principle of common but differentiated responsibilities with developed countries taking the lead in international environmental protection in view of their immense contributions to global environmental degradation and of the technologies and financial resources they command; fairness- by ensuring the actual participation of the developing countries in the global environmental governance system for example, in the management of global

141 Ivanova, supra nt 7, 18.

142 Biermann, F, "The Emerging Debate on the Need for a World Environment Organization: A Commentary" 1(1) Global Environmental Politics (2001), 45, 54.

143 Biermann, supra nt 29.

144 Biermann, supra nt 32. 
environmental funds; promote capacity-building and technology transfer so as to facilitate the implementation of agreements and the development of national policies aimed at environmental protection.

These recommendations, if adopted, will no doubt help to secure the full cooperation, participation and involvement of all especially developing countries in the proposed World Environment Organization, improve global environmental governance and help to tackle the several pressing global environmental problems more efficiently and successfully. 